\title{
James MacMillan's Liturgical Music Involving the Singing Congregation
}

\author{
Manfred Novak
}

\section{Introduction}

Any music composed after the Second Vatican Council and meant to be used in the framework of Roman Catholic liturgy needs to meet the Council's requirements in terms of participatio actuosa, the active participation of the entire assembly - one of the key terms of the Council. Composers of such music are therefore required to meet these concepts if they want to meet Roman Catholic official decisions, ${ }^{1}$ and James MacMillan is no exception here. ${ }^{2}$ The question

1 Cf. for example the Second Vatican Council's Constitution on the Sacred Liturgy Sacrosanctum Concilium n. 121: "Let them [i. e. composers] produce compositions which have the qualities proper to genuine sacred music, not confining themselves to works which can be sung only by large choirs, but providing also for the needs of small choirs and for the active participation of the entire assembly of the faithful".

2 It is important to understand that only after the liturgical reform of the Second Vatican Council the assembly was allowed and granted the right to celebrate liturgy. Prior to the Council's reform it was only the priest celebrating liturgy while the assembly silently watched him or engaged in devotional activities that might have included singing sacred but non-liturgical(!) songs which might or might not have had any connection to what the priest was doing. In any case, whatever the congregation did and sang had no relevance for the liturgical celebration. With the beginning of the $20^{\text {th }}$ century, liturgical movements and papal documents (Pius X, "Tra le sollecitudini," 1903; Pius XI, "Divini cultus sanctitatem," 1928 ) strove to give the congregation some part in the liturgy (firstly by joining in the singing of Gregorian chant), initially with a pastoral goal in mind. The Second Vatican Council took up the developing concept of participatio actuosa, made it to its key term and acknowledged that, "vi Baptismatis" (Sacrosanctum Concilium n. 14; engl.: "by reason of their baptism"), it is the entire assembly's "ius [...] et officium" (Sacrosanctum Concilium n. 14; engl.: "right and duty") to celebrate liturgy (in contrast to only the priests celebrating liturgy by reason of their ordination). Aspects of the Council's liturgical reform such as adapting the form of the rite, issuing new missals and permitting vernacular languages to the liturgy all have their reason in the necessity of enabling the entire assembly to celebrate. Thus, participatio actuosanot least with regard to liturgical singing - is not a desirable option to keep a congregation busy, but a theological requirement for celebrating liturgy. See also Luigi Girardi, “Tätige Teilnahme: Der Bedeutungswandel eines Konzils-Themas,” Singende Kirche 66, no. 2 (2019): 104-07; Rudolf Pacik, "Aktive Teilnahme: Schlüsselbegriff der erneuerten Liturgie," in Im Klangraum der Kirche: Aspekte - Positionen - Positionierungen in Kirchenmusik und Liturgie, ed. Martin Hobi (Luzern: Chronos, 2007), 27-52. 
how he writes in line with the concept of participatio actuosa in his compositions involving a congregation, be that a conscious decision or hypothetically motivated by any other (non-liturgical) reason, even if still fitting with the key term, will be dealt with in this article. This question includes aspects of composition technique, namely how to compose for musically uneducated singers on one hand, on the other, however, also of liturgy-theological positions, which are expressed in compositions. Another point in question concerns stylistic aspects: In how far do MacMillan's compositions for a congregation show compromises, and (how) are such compromises artistically justifiable?

Subject of the discussion shall be the following works involving congregational participation:

1. St Anne's Mass, composed in $1985,{ }^{3}$ revised in 1996 and adapted for the new English translation of the Roman missal in 2011. The mass is written for congregation and organ, the four-part choral settings for the "Sanctus" and the Memorial Acclamation are optional.

2. The Galloway Mass (1996), composed for the celebration of the $1600^{\text {th }}$ anniversary of the diocese of Galloway in $1997 .{ }^{4}$ In addition to congregation and organ this work requires at least a cantor or, alternatively, a four-part choir.

3. Advent Antiphons, which MacMillan composed around 1990 for his own liturgical practice. ${ }^{5}$ They are scored for congregation, cantor, twopart male choir and organ and set the Introitus and Communio texts of the four Sundays of Advent time to music.

4. Mass (2000, revised in 2012, new translation). It was commissioned by the professional choir of Westminster Cathedral ${ }^{6}$ and is musically the most complex work. In addition to the demanding choir setting and organ part MacMillan also wrote parts for the priest and the congregation in his setting of the Eucharistic Prayer.

5. Mass of Blessed John Henry Newman (2010) originated for the occasion of the papal visit to Great Britain in 2010. The minimal setting is for

3 It was written for St Anne's Church in Mossblown, Ayr, Scotland. See Stephen Kingsbury, "Aesthetic Meaning in the Congregational Masses of James MacMillan," Yale Journal of Music E' Religion 2, no. 1 (2016): 80.

4 The work was written for a national pilgrimage on this occasion and was premiered in Galloway Cathedral on March 25, 1997. See Kingsbury, "Aesthetic Meaning," 81.

5 For the first performance, MacMillan filled the part of the cantor himself. The composition only got published in 2012. See the CD-booklet to Who are these Angels? New Choral Music by James MacMillan, Linn Records (2011): 10.

6 The premiere of this mass composed for the millennium took place on the Feast of Corpus Christi. 
cantor, ${ }^{7}$ congregation and organ. Additionally there are optional parts for choir, two trumpets, two trombones and timpani.

People meeting as a liturgical congregation come from all professions and backgrounds and for the majority are untrained singers. Therefore any piece written with their active participation in mind will have to follow other rules than any piece written for (professionally) trained vocalists, as new sacred compositions outside (or even inside) the liturgy nowadays often are. Helpful in reducing the musical requirements for singing congregations are rather short, repeating or recurring motifs or phrases such as acclamations, responds, refrains and ostinatos and the elimination of some of the musical elements normally required simultaneously (the use of the speaking voice would eliminate the melodic aspect; aleatory elements may eliminate the aspect of fixed pitch or rhythm/timing). Quoting from melodies or songs already known to the congregation is another option to help facilitate the participation of the congregation in new liturgical music. All these techniques ${ }^{8}$ reduce or eliminate the necessity to study the music prior to performance or to be able to sing at sight (both of which are often no options with liturgical assemblies).

Most interestingly, however, James MacMillan only occasionally relies on these techniques but more often uses newly composed melodies for lengthy

7 The cantor mostly acts as a support for the congregation part, his soloistic part in "Kyrie" and the intonation of the "Gloria" can also be sung by the priest.

8 The author's research shows that all these techniques are actually used by composers when writing liturgical music for congregations, see Manfred Novak, "Providing for the Active Participation of the Entire Assembly': Petr Eben's Liturgical Music with Congregational Participation,” Musicologica Olomucensia 22, no. 2 (2015): 79-96; Manfred Novak, "Zeitgenössische liturgische Musik in St. Lambrecht: Uraufführungen im 21. Jahrhundert,” in Orgelbau, Orgelspiel und Kirchenmusik, einst und jetzt, ed. Manfred Novak (Wien: LIT-Verlag, 2013), 163-94; Manfred Novak, "Zeitgenössische Musik für zeitgenössische Liturgie: Liturgische Werke Ernst Kreneks nach dem II. Vatikanischen Konzil mit Gemeindebeteiligung," Singende Kirche 58, no. 3 (2011): 127-33; Manfred Novak, "The Second Vatican Council and the Contemporary Composer: Continuously Conflicting Concepts or Ways towards Reconciliation?” in Principles of Music Composing: Sacred Music X, ed. Rimantas Janeliauskas (Vilnius: Lietuvos muzikos ir teatro academija, 2010), 23-33; Manfred Novak, "Liturgische Komposition in Wien im Licht der Liturgiekonstitution Sacrosanctum Concilium und ihren Folgedokumenten," in Musikgeschichte in Mittel- und Osteuropa: Mitteilungen der internationalen Arbeitsgemeinschaft an der Universität Leipzig, vol. 12 (Leipzig: Gudrun Schroder Verlag, 2008), 179-88. Jörg Herchet is the only composer of whom the author knows that he used aleatory elements in his compositions involving the congregation, see DAS GEISTLICHE JAHR. kantate zum 3. sonntag nach epiphanias. komposition für violine, violoncello, klavier und publikum. This piece seems suited best for Lutheran liturgy, although the composer sees it open for usage in other liturgical rites, too. 
amounts of text. ${ }^{9}$ This choice entrusts a lot of previously unknown musical material to the congregation and can generally be rated as rather difficult for the members of the congregation, as they have to sing at sight a part new to them, if rehearsals beforehand are out of question. And so it is interesting to investigate what kind of support MacMillan offers the congregation so that they can participate in his music.

\section{Aspects of composition technique}

By making use of motivic connections up to exact repetition of selected passages not only does he create compositional coherence between the individual movements but also reduces the amount of melodic material that the congregation has to learn. If the same music is used again, even if possibly in another context, it will no longer seem entirely new, but will be at least subconsciously recognized at the later occurrence.

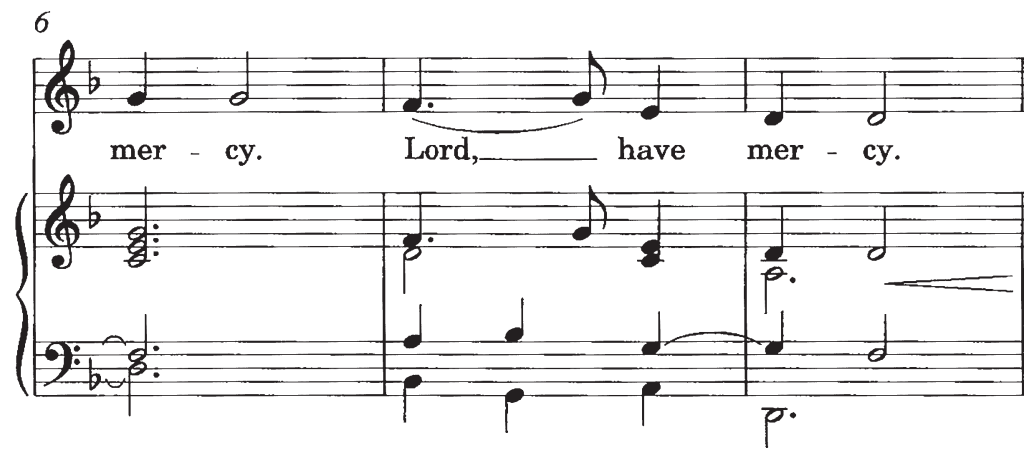

Music example 1a: James MacMillan, St Anne's Mass, "Kyrie," bb. 6-8

9 Of his movements/pieces with congregational participation the following use facilitating techniques as described above: "Gloria" of The Galloway Mass (respond); "Kyrie" of The Galloway Mass (acclamation) and "Kyrie" of Mass of Blessed John Henry Nerwman (acclamation, quotation); "Sanctus" of St Anne's Mass (quotation: however, the facilitating effect depends on the assembly's familiarity with the quoted melody from MacMillan's The Tryst); "Advent Antiphons" (respond: however, the respond is not being sung prior to the congregation's entry, so they do not have the opportunity to learn it during the performance); "Sursum corda" of Mass (acclamation). Thus, the following movements would qualify as "newly composed melodies for lenghty amounts of text": "Sanctus and Benedictus", "Acclamation" and "Agnus Dei" of The Galloway Mass; "Gloria", "Sanctus", "Acclamations", "Great Amen" and "Agnus Dei” of Mass of Blessed John Henry Newman; "Kyrie”, "Gloria”, “Acclamations", "Great Amen”, and "Agnus Dei” of St Anne's Mass; "Memorial Acclamations" of Mass. 
6

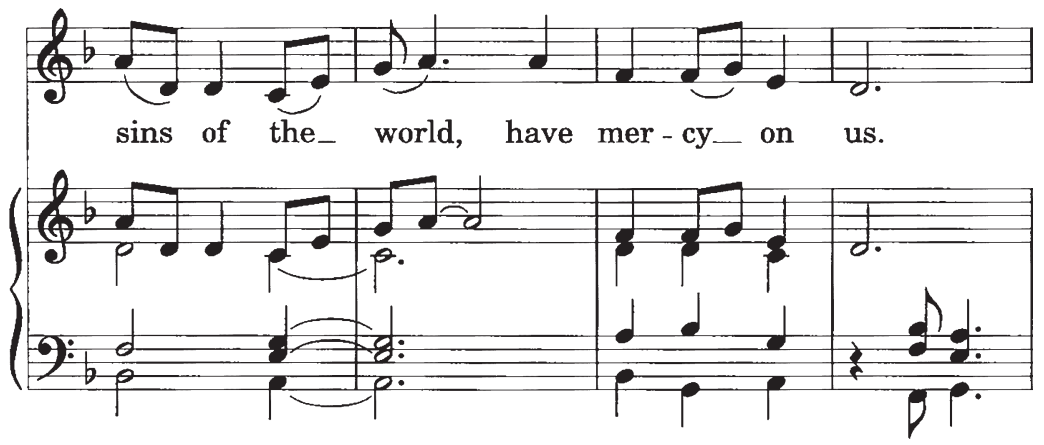

Music example 1b: James MacMillan, St Anne’s Mass, "Agnus Dei," bb. 6-910

In St Anne's Mass "Kyrie" and "Agnus Dei” are connected motivically (example 1), through forms such as ABA or AA'B respectively, melodic passages repeat within one movement, and also the $B$-parts show motivic relationship to the A-parts. The "Sanctus" is written in AA'-form, with the A'-part being reused for the "Acclamations". ${ }^{11}$ The "Gloria" of St Anne's Mass has been integrated into the mass only at a later point of time: It solely makes use of melodic elements of the "Sanctus", however, arranges them in a new way and, in contrast to the metrically composed "Sanctus", is composed in a rhythmically free form and notated with stemless notes (example 2).

${ }_{10}$ James MacMillan, St Anne's Mass: (c) Copyright 1997 by Boosey \& Hawkes Music Publishers Ltd. Revised version: (c) Copyright 1997, 2011 by Boosey \& Hawkes Music Publishers Ltd. Excerpts from the English translation of The Roman Missal (c) 2010, International Commission on English in the Liturgy Corporation. All rights reserved. Reproduced by permission of Boosey \& Hawkes Music Publishers Ltd. Solely for the use of Manfred Novak in the publication 'Musicologica Olomucensia'.

${ }^{11}$ For formal and structural aspects of St Anne's Mass see Kingsbury, "Aesthetic Meaning”. It should be mentioned, however, that Kingsbury does not include the movements "Gloria" and "Great Amen" in his study. 


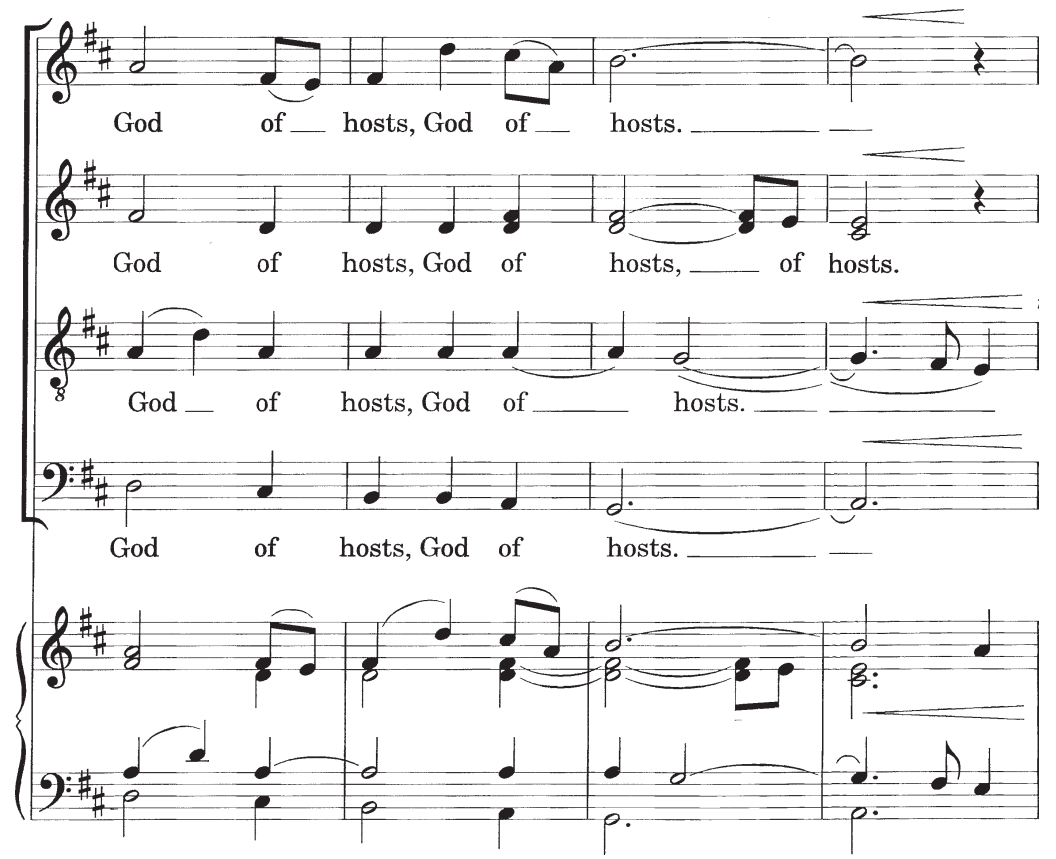

Music example 2a: James MacMillan, St Anne's Mass, "Sanctus," bb. 9-12

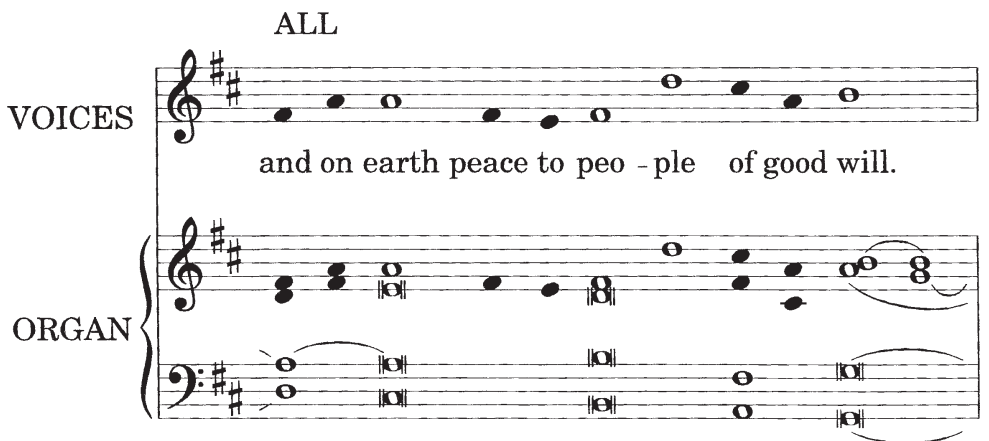

Music example 2b: James MacMillan, St Anne's Mass, "Gloria," b. $2^{12}$

12 James MacMillan, St Anne's Mass: (c) Copyright 1997 by Boosey \& Hawkes Music Publishers Ltd. Revised version: (c) Copyright 1997, 2011 by Boosey \& Hawkes Music Publishers Ltd. Excerpts from the English translation of The Roman Missal (c) 2010, International Commission on English in the Liturgy Corporation. All rights reserved. Reproduced by permission of Boosey \& Hawkes Music Publishers Ltd. Solely for the use of Manfred Novak in the publication 'Musicologica Olomucensia'. 
Thus, for those congregation members who are already familiar with the St Anne's Mass, the "Gloria" is easy to learn. Those, who sing the expanded version including the "Gloria" for the first time, will profit from the common compositional material shared by "Gloria", "Sanctus" and "Acclamations".

MacMillan takes a similar approach in The Galloway Mass, however, he also makes use of other, and for the congregation simpler, ways of participation: The "Kyrie" is kept antiphonally, with the cantor singing the congregation's melody ahead of them. In the "Gloria" the congregation is involved with a refrain. At its initial occurrence, alike earlier in the "Kyrie", this refrain is introduced in unison. Additionally, in the "Kyrie" almost all of the material of the remaining movements gets already presented. ${ }^{13}$

In Mass MacMillan again makes use of the antiphonal structure of the liturgical text in the movement "Sursum corda" in order to have the congregation repeat the previously sung melody (example 3).

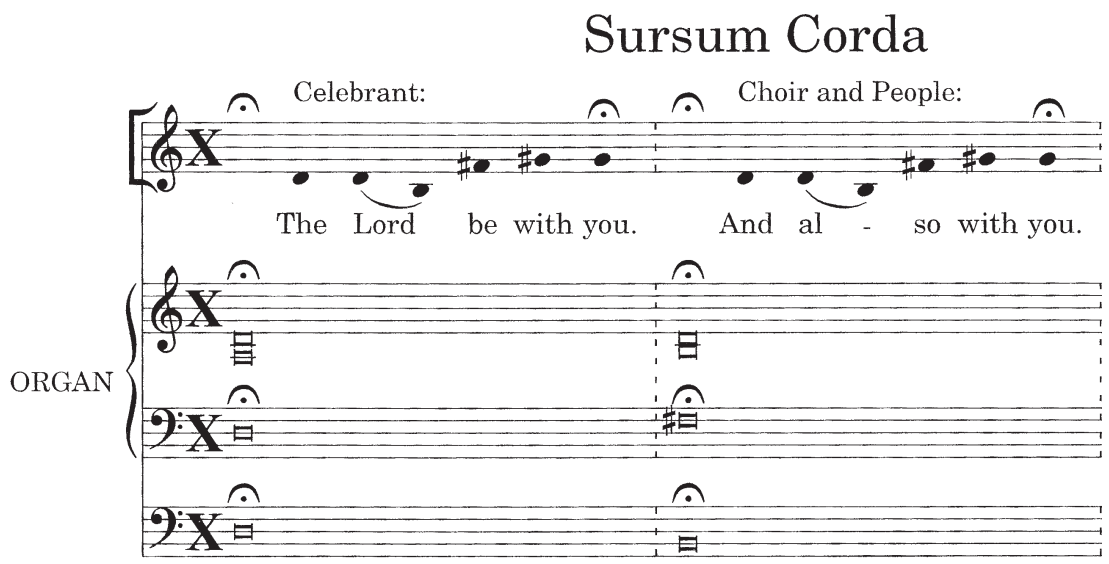

Music example 3: James MacMillan, Mass, "Sursum Corda," bb. 1-2 ${ }^{14}$

13 The refrain of the "Gloria" and the "Agnus Dei" have been created inspired from the melody of the "Kyrie", the Amen of the "Gloria" repeats the music of the organ prelude of that movement, "Sanctus and Benedictus" take their melody from the "Gloria", "Acclamation" reuses music from parts of "Sanctus and Benedictus", and "Great Amen" makes use of the same music as the "Amen" at the end of the "Gloria". For formal and structural aspects of The Galloway Mass see Kingsbury, "Aesthetic Meaning”. Kingsbury does not discuss the thematic-motivic relationship between "Kyrie" and the refrain of the "Gloria".

${ }^{14}$ James MacMillan, Mass: (c) Copyright 2000 by Boosey \& Hawkes Music Publishers Ltd. Reproduced by permission of Boosey \& Hawkes Music Publishers Ltd. Solely for the use of Manfred Novak in the publication 'Musicologica Olomucensia'. 
For the acclamations in the Eucharistic Prayer (Memorial Acclamation and Amen) the congregation has to enter immediately after the intonation of the priest (example 4); their phrase, however, has long been familiar to them: It was used in the "Kyrie" three times as an acclamation, and was repeated in the Institution Narrative another four times; additionally, the head motif got quoted eight times in the "Gloria" and in the "Sanctus" was used as the fugato subject.

\section{Memorial Acclamations}

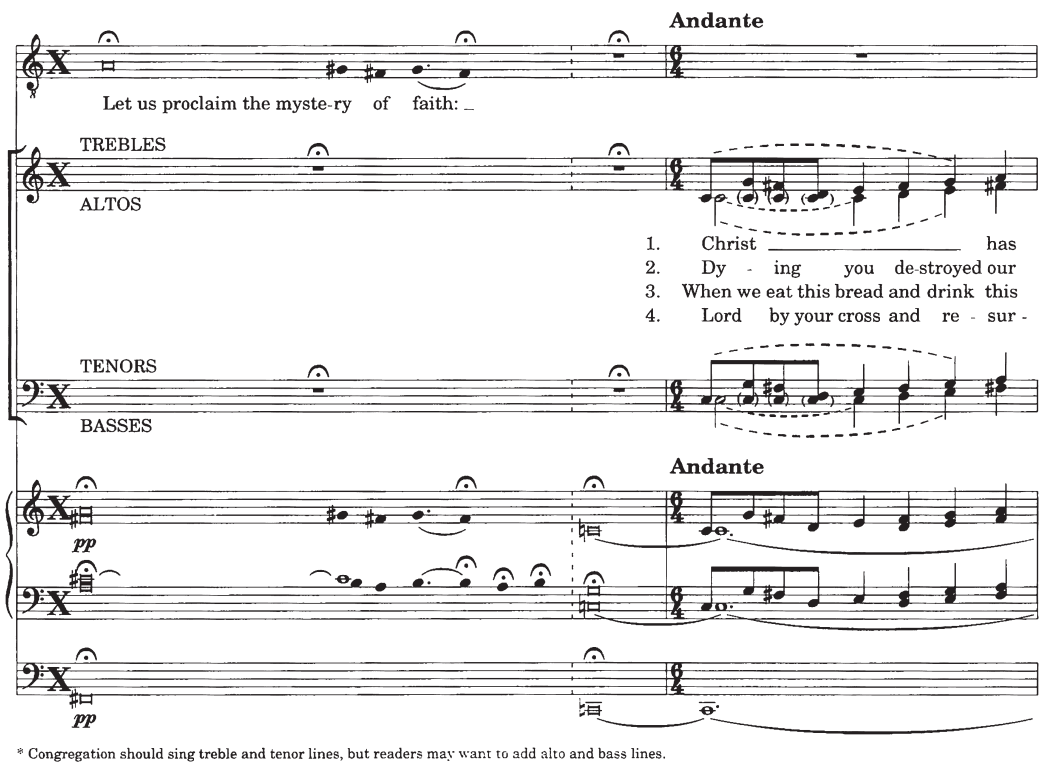

Music example 4: James MacMillan, Mass, “Memorial Acclamations," bb. 1-315

In Mass of Blessed John Henry Nerwman MacMillan again puts trust in longer newly composed passages for the congregation. Solely the "Kyrie" is planned antiphonally (example 5), the short motif is introduced by the cantor, and already in the organ prelude was used as a quasi ostinato - this being the only example of the congregation taking part in an ostinato in MacMillan's works known to the author.

${ }^{15}$ James MacMillan, Mass: (c) Copyright 2000 by Boosey \& Hawkes Music Publishers Ltd. Reproduced by permission of Boosey \& Hawkes Music Publishers Ltd. Solely for the use of Manfred Novak in the publication 'Musicologica Olomucensia'. 


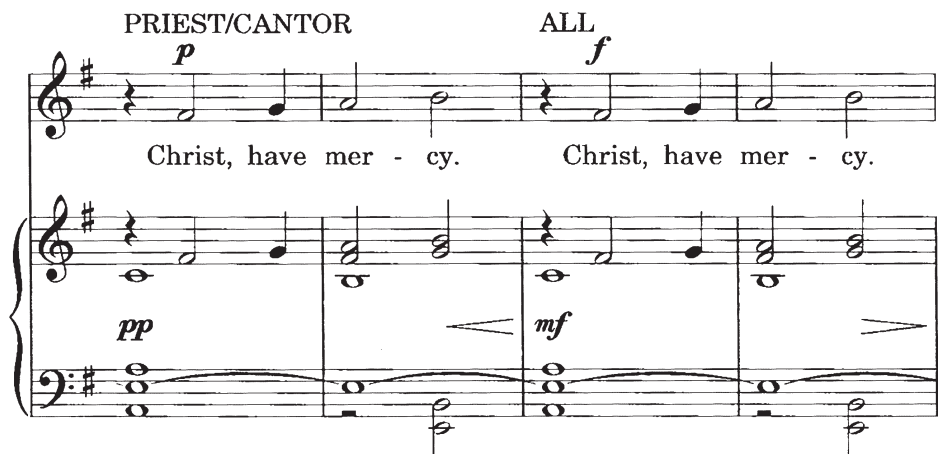

Music example 5: James MacMillan, Mass of Blessed John Henry Newman, "Kyrie," bb. 7-10

"Gloria" and "Sanctus" both introduce new material, and with relation to their text structure include melodic repetitions within each individual movement. ${ }^{17}$ The "Acclamations" consist entirely of music used earlier already, ${ }^{18}$ the "Agnus Dei" starts from a diminution of the Kyrie acclamation (example 6).

${ }_{16}$ James MacMillan, Mass of Blessed John Henry Newman: (c) Copyright 2010 by Boosey \& Hawkes Music Publishers Ltd. Reproduced by permission of Boosey \& Hawkes Music Publishers Ltd. Solely for the use of Manfred Novak in the publication 'Musicologica Olomucensia'.

17 In "Gloria" one short motif appears two or three times before a change to another motif is made, in "Sanctus" the text of the "Benedictus" is being sung on a diatonic transposition of the melody of the "Sanctus"-section.

18 The "Memorial Acclamations" use music from "Sanctus", "Great Amen" and from the ending of "Gloria". 


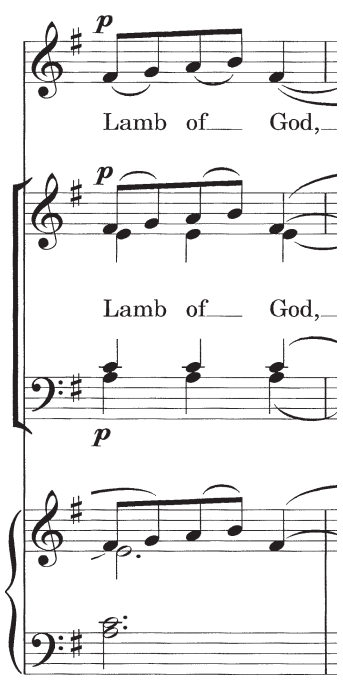

Music example 6: James MacMillan, Mass of Blessed John Henry Newman, “Agnus Dei,” b. $7^{19}$

Advent Antiphons serve as an example for music in which the congregation actually need to learn and know their melody ahead of the celebration. However, even so there are four factors to ease their process of learning: Firstly, the melody is diatonic, preferably moving stepwise, and of a length that can still be overlooked well. Secondly, the antiphon has eight different textual underlays ${ }^{20}$ this being the reason that it can be used on four consecutive Sundays, and even twice per Sunday, which makes it possible that it can also be learnt by repetition. Thirdly, for each individual usage of the antiphon it is sung three times alternating with the solo verses, this being another possibility to learn by repetition. Finally, the congregation part is doubled in the organ part and can further be supported by the female voices of the choir and/or the cantor (example 7).

19 James MacMillan, Mass of Blessed John Henry Nerwman: (c) Copyright 2010 by Boosey \& Hawkes Music Publishers Ltd. Reproduced by permission of Boosey \& Hawkes Music Publishers Ltd. Solely for the use of Manfred Novak in the publication 'Musicologica Olomucensia'.

${ }^{20}$ These are always the Introitus and the Communio for each of the four Sundays of Advent time. 


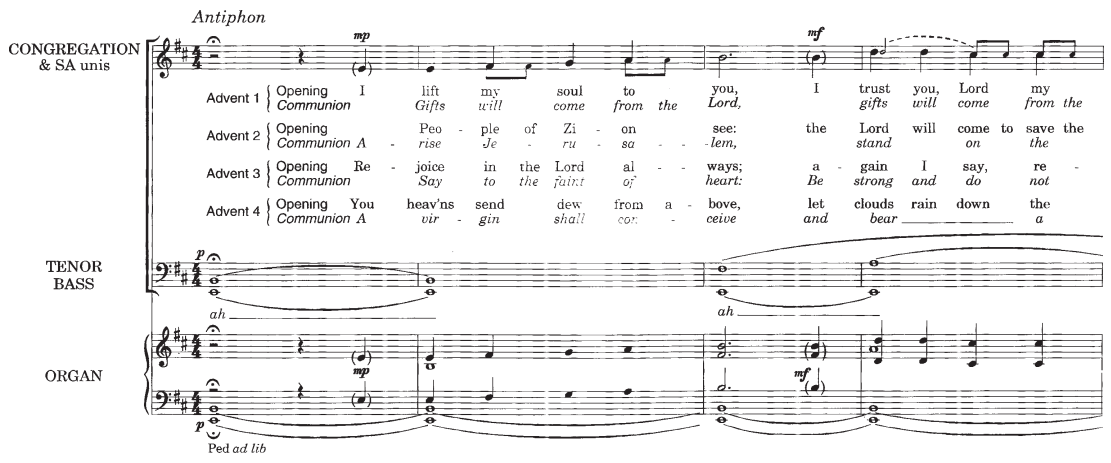

Music example 7: James MacMillan, Advent Antiphons, bb. 1-4 ${ }^{21}$

This last point of a double support is the case for almost all the congregation parts in MacMillan's liturgical music. ${ }^{22}$

Additionally, working with quotations from his own or also foreign compositions - a technique that is frequently found in MacMillan's entire compositional oeuvre - can help a congregation, provided the quoted music is at least latently known to them, so that recognition and/or a certain level of familiarity can be achieved in this way. The Sanctus melody of St Anne's Mass, e.g., is taken from an earlier work by MacMillan, The Tryst (1984), ${ }^{23}$ and the "Kyrie" of the Mass of Blessed John Henry Newman quotes Richard Wagner's Tristan und Isolde $e^{24}{ }^{25}$

${ }^{21}$ James MacMillan, Advent Antiphons: (c) Copyright 2011 by Boosey \& Hawkes Music Publishers Ltd. Reproduced by permission of Boosey \& Hawkes Music Publishers Ltd. Solely for the use of Manfred Novak in the publication 'Musicologica Olomucensia'.

${ }^{22}$ Exceptions to this are solely two movements from Mass of Blessed John Henry Nerwman: In "Gloria" the organ leaves the congregational part for the length of in total six measures, and in "Agnus Dei" there is a short overlap of the sung addresses and the organ interludes, when during the last or second last tone of the congregation's line the organ already starts its soloistic part. If, for the St Anne's Mass, one chooses the performance option without cantor and without choir, the only remaining support for the congregation in this version will be the organ.

${ }^{23}$ Dominic Wells, "Singing the Same Song: Bridging the Sacred/Secular Boundary in the Mass Settings of James MacMillan," in Principles of Music Composing: Sacred Music X, ed. Rimantas Janeliauskas (Vilnius: Lietuvos muzikos ir teatro academija, 2010), 92-93.

${ }^{24}$ For the quotation from Wagner see the CD-booklet to Who are these Angels?, 9.

${ }^{25}$ Mass takes up material from MacMillan's Quickening (1998) anew. The liturgical music with congregational participation (The Galloway Mass, Mass, Mass of Blessed John Henry Newman) itself becomes the source for later compositions of MacMillan and is thus intimately involved in his complete oeuvre. On this topic, cf. Wells, "Singing the Same Song"; Dominic Wells, "James MacMillan: Retrospective Modernist” (PhD diss., University of Durham, 2012), 140-51, 330-35; Kingsbury, "Aesthetic Meaning". 
As has been shown, most importantly repetition and recurrence enable and ease participation for the congregation. ${ }^{26}$ Thanks to two techniques MacMillan frequently also uses in his non-liturgical music, namely varying harmonization of melodically identical motifs or phrases ${ }^{27}$ and thematic transformation ${ }^{28}$, the thematic repetitions do not end up monotonous. Thematic transformation can get executed with regard to pitch, here options such as transposition, substracting or adding of notes and transformation into another mode should be named, or with regard to rhythm, if the same melodic element is being set into a rhythmic proportion ${ }^{29}$ or set to a differing rhythm, or also, if change between metric and free-rhythmic performance occurs. Naturally, any kind of combination of the mentioned techniques is possible.

Up to this point in his argument the author has discussed the part of the congregation and their ease of performance in a mostly isolated way. With regard to additional performers further practical questions of common music-making arise: How will the congregation find their entrance pitch, the right point of time for their entry and the right tempo?

Pitch and tempo are easy to pick for the congregation either from a preceding organ prelude or also from a preceding solo or choir part ending at their starting pitch or already anticipating an upcoming entrance motif. In singular cases, when the tempo would not get established beforehand, the cantor or choir sing an identical part and with regard to tempo need to "carry along" the members of the congregation (see music example 4).

To find the right time of entrance is oftentimes more difficult for a congregation. In case of antiphonal writing they can take up the breath impulse of the cantor (example 8).

${ }^{26}$ This repetition or recurrence can be structuring, as in case of ostinati or refrains. In comparison with other composers, however, MacMillan more often writes longer newly composed parts for congregation.

${ }^{27}$ Stephen Kingsbury, “The Early Choral Music of James MacMillan: 1983-1993” (PhD diss., University of of Illinois at Urbana-Champaign, 2003), 257. Kingsbury names The Seven Last Words and Cantos Sagrados as examples. For examples in liturgical works, see "multiple harmonization" in the table on pages 101-102 of this article.

${ }^{28}$ Kingsbury, "Early Choral Music", 235-59. Kingsbury also offers an example of this from St Anne's Mass ("Agnus Dei", 245). For further examples in liturgical works, cf. the table on page 101f.

${ }^{29}$ Metric modulation. 


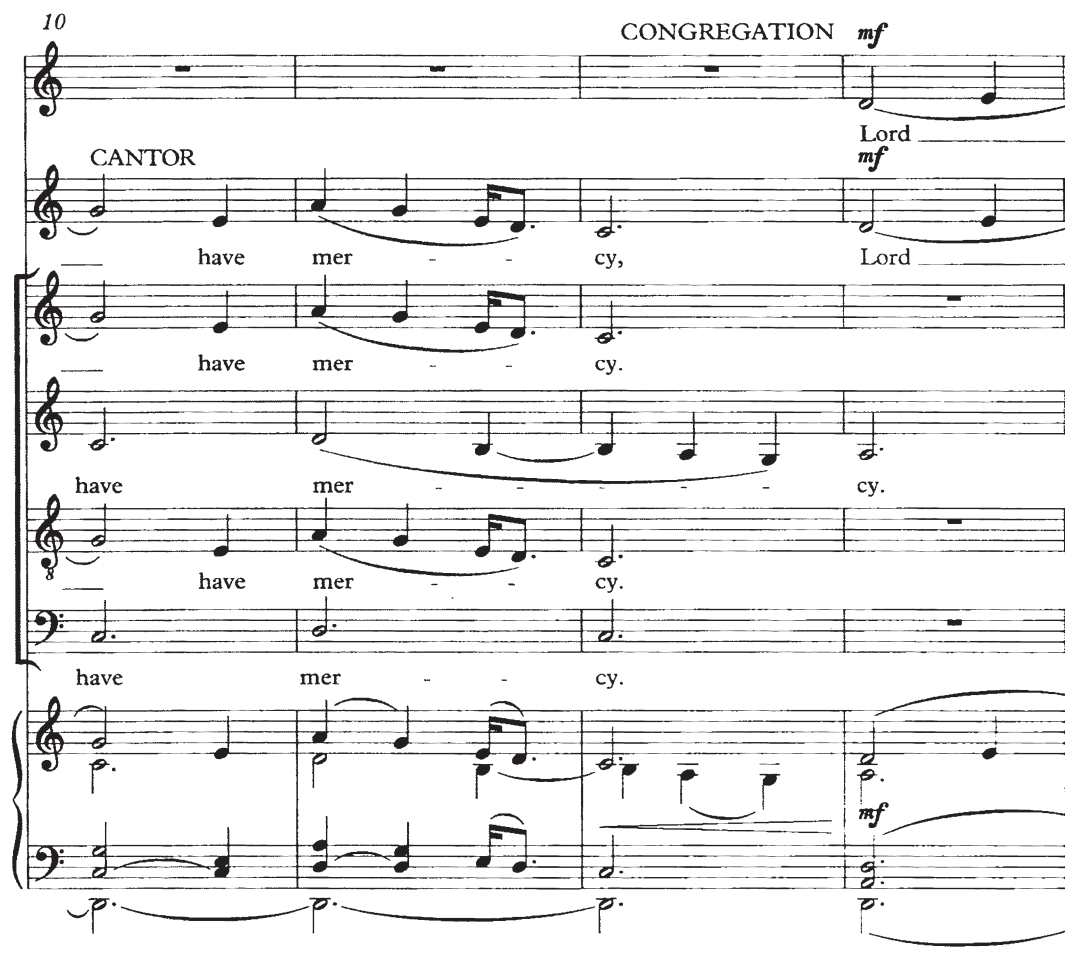

Music example 8: James MacMillan, The Galloway Mass, "Kyrie," bb. 10-1330

Should they, however, start after the organ they will only rarely receive a breath impulse due to the fact that MacMillan makes them enter into a stationary sound (see music example 7). Similarly, an entry of the congregation on the tonic which overlaps with the end of the organ prelude seems tricky to the author (example 9).

${ }^{30}$ James MacMillan, The Galloway Mass: (c) Copyright 1997 by Boosey \& Hawkes Music Publishers Ltd. Reproduced by permission of Boosey \& Hawkes Music Publishers Ltd. Solely for the use of Manfred Novak in the publication 'Musicologica Olomucensia'. 


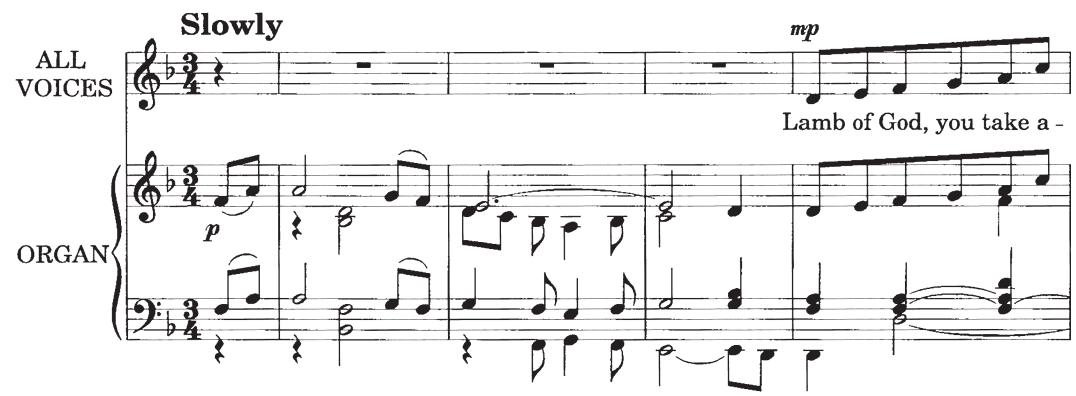

Music example 9: James MacMillan, St Anne's Mass, "Agnus Dei," bb. 1-4

A safer way is to arrive at the tonic already before the entry of the congregation, as is the case for the "Kyrie" of St Anne's Mass (example 10).

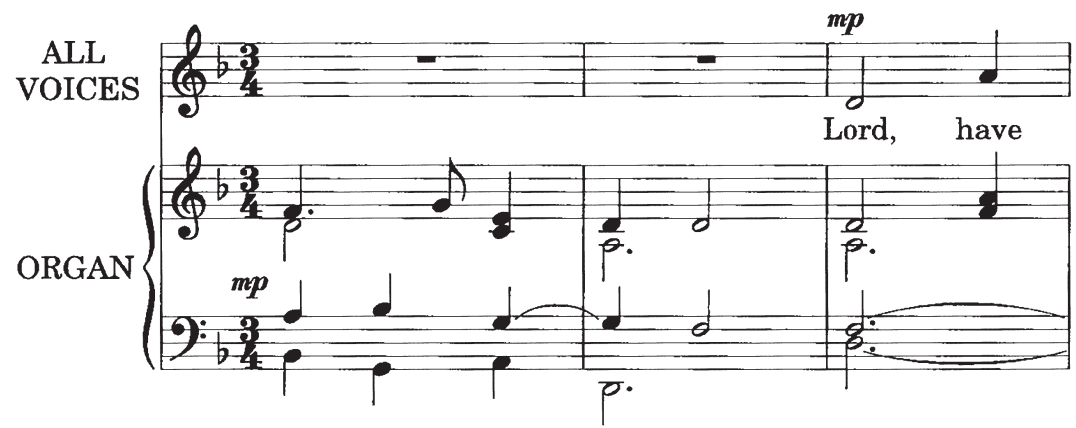

Music example 10: James MacMillan, St Anne's Mass, "Kyrie," bb. 3-532

This also allows the organist to provide a "breath impulse" by releasing the last note in measure four ("Kyrie") one crotchet earlier. As a rule, however, MacMillan

${ }^{31}$ James MacMillan, St Anne's Mass: (c) Copyright 1997 by Boosey \& Hawkes Music Publishers Ltd. Revised version: (c) Copyright 1997, 2011 by Boosey \& Hawkes Music Publishers Ltd. Excerpts from the English translation of The Roman Missal (c) 2010, International Commission on English in the Liturgy Corporation. All rights reserved. Reproduced by permission of Boosey \& Hawkes Music Publishers Ltd. Solely for the use of Manfred Novak in the publication 'Musicologica Olomucensia'.

32 James MacMillan, St Anne's Mass: (c) Copyright 1997 by Boosey \& Hawkes Music Publishers Ltd. Revised version: (c) Copyright 1997, 2011 by Boosey \& Hawkes Music Publishers Ltd. Excerpts from the English translation of The Roman Missal (c) 2010, International Commission on English in the Liturgy Corporation. All rights reserved. Reproduced by permission of Boosey \& Hawkes Music Publishers Ltd. Solely for the use of Manfred Novak in the publication 'Musicologica Olomucensia'. 
by stationary tones, crescendi, ${ }^{33}$ or harmonic progression goes for a tight weave and continuation of the organ part in the places of congregation entries. It seems that, different from the author's own experience in German-speaking areas, this is a sign of an accompaniment practice in which the congregation for their entry are dependent on the cantor or choir director and visual cues given by them to a higher degree.

\section{Liturgy-theological positions}

Quite noteworthy are also several liturgy-theological positions that are expressed in MacMillan's music. On one hand, conservative elements are found which strongly connect to the (pre-Council) tradition. Among them is the composition of ordinary cycles, as the combination of these movements into a musical cycle does not have any theological or ritual basis, ${ }^{34}$ and equally the choice of texts of the missal for elements which have been open to replacement by other texts since the advent of the post-Council missals. ${ }^{35}$ More striking, however, are elements of the liturgy reform of the Second Vatican Council which get featured in MacMillan's work contrasting with the pre-Council tradition of writing mass cycles: He composes a comparatively high amount of liturgical music for congregation (in contrast to the pre-Vatican II-cycles of the ordinarium missae executed by choirs without the congregation), and for this purpose always chooses the English mother tongue (in contrast to the pre-Vatican II-cycles of the ordinarium missae in Latin/Greek). ${ }^{36}$ In his mass compositions he gives more musical weight to the Eucharistic Prayer by setting the acclamations to music (for the Memorial Acclamation and the concluding Amen), and in a liturgically sensible way always entrusts these to the congregation (in contrast to the pre-Vatican II-cycles of the ordinarium missae lacking such congregational acclamations). ${ }^{37} \mathrm{He}$ cares for practical aspects of integration of the music into the dramaturgical plan of the liturgy: Together with the acclamations of the

${ }^{33}$ E.g. in the "Gloria" of The Galloway Mass.

${ }^{34}$ Nowadays, aside of the connection to the musical (and liturgical) tradition, the main reason for the continuation of the practice of composing mass ordinary cycles seems to be the practical aspect: With regard to their text they can be used in any mass service.

35 In his Advent Antiphons and his Strathclyde Motets (without congregational participation) MacMillan sets such "Introitus- and Communio texts" to music. Also, he adapted earlier compositions after the publication of the new official English translation of the missal to mirror this new text (St Anne's Mass, Mass).

${ }^{36}$ MacMillan also sets Latin texts for the liturgy to music (verses of the Advent Antiphons, Missa brevis, Missa Dunelmi, Strathclyde Motets), but does not dedicate them to the congregation for performance.

${ }^{37}$ In the masses without congregational participation (Missa brevis, Missa Dunelmi) these acclamations are not set to music. 
Eucharistic Prayer he notates on which pitch the priest should start the liturgical recitative of the missal in order to be able to find a sensible musical transition from the recitation to the composed acclamations, and he would frequently set a short prelude at the start of the acclamations in order to ease the entry for the congregation. The "Acclamations" of St Anne's Mass additionally are provided in a printed transposition so that there is a choice of two different pitches for the liturgical recitative and the "Acclamations" available.

Especially interesting - with regard to the liturgical integration - is Mass, as in this case MacMillan composes an entire Eucharistic Prayer, starting from the initial dialogue between priest and congregation and lasting till the Amen (in contrast to the pre-Vatican II-cycles of the ordinarium missae, none of which had an Eucharistic Prayer set to music). This allows him to treat priest, congregation, organist and choir according to their liturgical distribution of roles and according to their musical abilities, ${ }^{38}$ to shape the Eucharistic Prayer as a musical unity and by that give it musical weight in the entire succession of the mass. To set the preface and the Eucharistic Prayer as a recitative allows for the usage of varying texts. Of specific interest is the compositional treatment of the Institution Narrative, where MacMillan through short organ solo parts provides time for wordless liturgical gestures (lifting of the offerings, genuflections, bells) and musically repaints them by writing either raising or descending lines.

Finally it should be mentioned that MacMillan has not composed any liturgical Credo ever, neither for congregation nor for choir, but did so for apparently practical reasons, as sung Credos have fallen out of use in the UK. ${ }^{39}$

\section{Stylistic aspects}

For stylistic questions of MacMillan's compositions with congregational participation the author makes use of existing treatises by Stephen Kingsbury ${ }^{40}$ and Timothy Rolls, ${ }^{41}$ to a smaller extent also by Dominic Wells. ${ }^{42}$

38 The "Sanctus" is set for choir, i.e. without priest and congregation. In the "Memorial Acclamations" MacMillan includes a second part for sight readers in the congregation. Both of these parts are supported by the organ.

39 The only Credo composition by MacMillan (Credo, 2012) is a concert piece. "As he [James MacMillan] has pointed out, musical settings of the Creed in a liturgical setting are no longer viable." (Paul Spicer, James MacMillan Choral Music: A Practical Commentary and Survey by Paul Spicer (London: Boosey \& Hawkes, 2012). http://www.boosey.com/downloads/ MacMillanChoralPDF12finalWEB.pdf: 22.)

${ }^{40}$ Kingsbury, "Early Choral Music".

${ }^{41}$ Timothy Michael Rolls, "James MacMillan: An analysis of selected works (1983-1997)" (PhD diss., University of Houston, 2000).

${ }^{42}$ Wells, "James MacMillan: Retrospective Modernist". 
From these scholarly works facts for a list of stylistic features were gathered for which then was specifically searched in the liturgical works with congregational participation. Omnipresent elements of MacMillan's music, such as the use of various diatonic scales ${ }^{43}$ have not been listed specifically.

\begin{tabular}{|c|c|c|c|c|c|}
\hline Stylistic feature & $\begin{array}{l}\text { St Anne's } \\
\text { Mass }\end{array}$ & $\begin{array}{l}\text { Advent } \\
\text { Antiphons }\end{array}$ & $\begin{array}{l}\text { The Galloway } \\
\text { Mass }\end{array}$ & Mass $^{44}$ & $\begin{array}{l}\text { Mass of } \\
\text { Blessed } \\
\text { John Henry } \\
\text { Newman }\end{array}$ \\
\hline $\begin{array}{l}\text { Stratified } \\
\text { polyphony }{ }^{45}\end{array}$ & & Ant, Vers & & Sc & $\mathrm{Ag}$ \\
\hline $\begin{array}{l}\text { Antiphonal } \\
\text { writing }\end{array}$ & & Ant + Vers ${ }^{46}$ & Ky, Gl & Sc & $\mathrm{Ky}, \mathrm{Ag}$ \\
\hline Ostinato $^{47}$ & & & & & Ky \\
\hline $\begin{array}{l}\text { Thematic } \\
\text { transformation }^{48}\end{array}$ & $\begin{array}{l}\text { Ky, Gl, Amen, } \\
\mathrm{Ag}\end{array}$ & Ant & $\begin{array}{l}\text { Gl, Sa, Accl, } \\
\text { Amen, Ag }\end{array}$ & & $\begin{array}{l}\text { Gl, Sa, Accl, } \\
\text { Amen, Ag }\end{array}$ \\
\hline $\begin{array}{l}\text { Metric } \\
\text { modulation }\end{array}$ & Amen & & Gl, Amen & & $\mathrm{Ag}^{49}$ \\
\hline $\begin{array}{l}\text { Multiple } \\
\text { harmonization }^{50}\end{array}$ & Gl, Amen & & $\begin{array}{l}\text { Ky, Gl, Amen, } \\
\mathrm{Ag}\end{array}$ & Sc, Accl & Ky, Gl, Ag \\
\hline Fauxbourdon ${ }^{51}$ & & $\mathrm{Gl}$ & & $\mathrm{Accl}$ & Sa \\
\hline
\end{tabular}

${ }^{43}$ These scales include major and minor scales, mediaeval modi, and pentatonic and hexatonic scales.

${ }^{44}$ Only the two movements with congregational participation, "Sursum Corda" (= Sc) and "Memorial Acclamations" (= Accl), have been included in the list.

45 This category includes techniques such as, e.g., polyrhythm, polymodality, and polytonality. In his music for congregation, however, MacMillan limits himself to much simpler layering of contrasting materials.

46 The antiphonal structure does not occur inside the antiphon or the verse but in this case can be seen in the alternation between antiphon and verse.

${ }^{47}$ The rather singular use of ostinato technique in MacMillan's liturgical music with congregational participation is matched by a similarly rare usage throughout his entire oeuvre.

${ }_{48}$ The thematic transformation can occur within one single movement or else depend on melodic relationship between various movements.

49 The opening motif is a diminution of the Kyrie.

${ }^{50}$ Varying harmonization of identical repetition of the melody.

${ }^{51}$ Kingsbury, Rolls and Wells do not mention fauxbourdon as a stylistic element of MacMillan's music, however, as a historical technique of tonal setting it fits well with MacMillan's general eagerness for connection with the musical tradition. The fauxbourdon technique has been included in the list because of its repeated occurrence in works with congregational participation, its occurrence can, however, also be seen in other works, such as The canticle of Zachariah (fauxbourdon over a drone), Qui meditabitur and Mitte manum tuam. Similarly, also other forms of parallel triads or triadic inversions can be found in MacMillan's works. Kingsbury generally points out techniques of mostly early sacred music in MacMillan's style, "[...] the allusion to historical methods of composition is one element of a fundamentally eclectic style" (Kingsbury, "Early Choral Music," 139). 


\begin{tabular}{|c|c|c|c|c|c|}
\hline Drones & $\mathrm{Ky}, \mathrm{Sa}, \mathrm{Accl}, \mathrm{Ag}$ & Ant & Ky, Gl, Accl, Ag & Accl & Sa, Accl \\
\hline $\begin{array}{l}\text { Scottish } \\
\text { features }^{52}\end{array}$ & Sa, Accl & Ant, Vers & $\begin{array}{l}\text { Ky, Gl, Sa, } \\
\text { Accl, Ag }\end{array}$ & & $\mathrm{GI},{ }^{53} \mathrm{Sa}, \mathrm{Accl}$ \\
\hline Glissando $^{54}$ & & Vers & & & \\
\hline Heterophony ${ }^{55}$ & & & $\mathrm{Ky}^{56}$ & & \\
\hline Quotation & Sa, Accl & & & & Ky \\
\hline $\begin{array}{l}\text { Plainchant/ } \\
\text { reciting tone }^{57}\end{array}$ & $\mathrm{Gl}$ & Vers & & Sc, Accl & $\mathrm{G}^{58}$ \\
\hline Chorale $^{59}$ & Sa, Accl & & & & $\mathrm{Gl}, \mathrm{Sa}, \mathrm{Accl}$ \\
\hline Organum & & & Ky, GI & Accl & \\
\hline
\end{tabular}

The above list ${ }^{60}$ shows that some prominent features of MacMillan's style do not show at all or just to a very minimal extent: These are diverse options of stratified polyphony such as polyrhythm ${ }^{61}$, polymodality or polytonality ${ }^{62}$ respectively, and heterophony, hocket, 12 -note chords, chain technique ${ }^{63}$ and aleatoricism ${ }^{64}$.

Nevertheless, the outcome shows that his liturgical music with congregational participation is stylistically clearly situated within the frame of his entire

52 Includes Scottish Snap and graces inspired by Pibroch.

53 Only occurs in the intonation of the Gloria.

${ }^{54}$ Inspired by keening (a Scottish type of moaning music).

55 Inspired by Gaelic psalm singing (a Scottish singing tradition).

${ }^{56}$ Heterophony is not a prominent feature but only occurs for short in some measures (cf. Alto-Bass in bb. 19-22).

57 Includes sections notated without stems, to be sung in speech rhythm, respectively non-metrically.

58 Only occurs in the intonation of the Gloria.

${ }^{59}$ Homorhythmic, non-dramatic texture in a relatively slow harmonic progression with smooth voice-leading (cf. Kingsbury, "Early Choral Music,"142-44).

${ }^{60}$ This list has been compiled for the author's lecture "James MacMillans liturgische Musik mit Gemeindebeteiligung" at the symposium "Junge Musikwissenschaft" in the course of the annual conference of the Austrian Society for Musicology on Oct. 7, 2016. In German language, it has been included in Manfred Novak, "Kunstvoll oder singbar? Kompositorische Beschränkung und künstlerisches Potenzial des Gemeindegesangs,” Singende Kirche 66, no. 1 (2019): 28-37.

${ }^{61}$ For examples of the use of polyrhythm in MacMillan's works see Cantos Sagrados, "Virgin of Guadalupe”, (see also Kingsbury, "Early Choral Music," 86-87) or Catherine's Lullabies (see also Kingsbury, "Early Choral Music," 90).

${ }^{62}$ For examples of the use of polytonality in MacMillan's works see The Worlds Ransoming (see also Rolls, "James MacMillan: Selected Works," 49-51), Veni, Veni Emmanuel (see also Rolls, "James MacMillan: Selected Works," 71, 79) or Britannia (see also Wells, "James MacMillan: Retrospective Modernist,” 216).

${ }^{63}$ Cf. Witold Lutosławski's "chain technique".

${ }^{64}$ For MacMillan's use of aleatoricism in his vocal works see for example So Deep or Catherine's Lullabies (see also Kingsbury, "Early Choral Music," 43, 46, 50-51, 94-98, 268). 
compositional oeuvre. ${ }^{65}$ Even if the parts for congregation show a melodic and rhythmical structure that is easier performable and the accompaniment is often made of triads or chords of four tones or organum and thus the complexity of the musical structure seems reduced, there are similar passages in other works by MacMillan, too. ${ }^{66}$ This outcome is not unexpected for MacMillan, who very consciously relates to musical tradition and makes use of various styles on one hand, on the other, however, also unites very different stylistic elements into a highly personal musical idiom ${ }^{67}$.

Thus, MacMillan is one of the few composers who managed to do justice to the required participatio actuosa without giving up on their own artistic demand. ${ }^{68}$ Frequently he indicated that, with regard to composition for congregation and liturgy, one had to leave one's compositional ego at the church porch.$^{69}$ However, the fact that he managed not to leave his artistic and technical abilities as a composer of international reputation at the church porch, too, gave us a number of compositions, simple at times, but elaborate, suggestive, and most appropriate to the new form and understanding of liturgy.

${ }^{65}$ Dominic Wells arrives at another assessment, namely that MacMillan only keeps up the Scottish elements in his works with congregational participation (Wells, "James MacMillan: Retrospective Modernist," 123-30). The Scottish elements of the list provided here are drones, Scottish graces, glissando and heterophony. Dominic Wells's characterisation of MacMillan's music with congregational participation as "ultra-simplified music" (Wells, "James MacMillan: Retrospective Modernist,"129) is certainly understandable, most of all for the reason that the metrical and rhythmical organisation seems strongly simplified. However, while MacMillan lets go entirely of some of his quite prominent stylistic features, one can clearly see that many elements of his personal style aside of the Scottish features are also present in his music for liturgical congregations: The list contains nine of them, out of which some (stratified polyphony, metric modulation) occur only in a rudimentary and simplified form, others (thematic transformation, multiple harmonization), however, show up in a very distinct way.

${ }^{66}$ Cf. The canticle of Zachariah, O Radiant Dawn, Mass (Gloria, bb. 34-40).

${ }^{67}$ Cf. the discrimination of "stylistic pluralist" and "polystylist" and the assessment that MacMillan was both (Wells, "James MacMillan: Retrospective Modernist," 250-53).

${ }^{68}$ For a more general discussion of how composing for congregations affects and relates to artistic considerations see Novak, "Kunstvoll oder singbar?".

69 "[...] in talks and conferences he [MacMillan] has frequently mentioned the necessity to "leave the compositional ego in the church porch"'(Wells, "James MacMillan: Retrospective Modernist," 129). 


\section{James MacMillan's Liturgical Music Involving the Singing Congregation}

\section{Abstract}

James MacMillan is one of the few internationally renowned composers who embraced the liturgical reform of the Second Vatican Council with its key concept of participatio actuosa and wrote music involving the congregation. With regard to these works, the following questions are discussed and answered: In what way did he compose for untrained singers so that they are able to sing his compositions? Which stylistic compromises did he accept and how are they artistically justifiable? How does his liturgical music involving the congregation relate to liturgical theological concepts?

\section{Liturgická hudba Jamese MacMillana zapojující zpívající kongregaci}

\section{Abstrakt}

James MacMillan je jeden z mála mezinárodně uznávaných skladatelů, kteří přijali liturgickou reformu druhého vatikánského koncilu s jejím klíčovým konceptem participatio actuosa a psal hudbu zapojující kongregaci. S ohledem na tato díla jsou diskutovány a zodpovězeny následující otázky: Jakým způsobem skládal pro netrénované zpěváky tak, aby byli schopni zpívat jeho skladby? Které stylové kompromisy přijal a jak je lze umělecky ospravedlnit? Jak se jeho liturgická hudba zapojující kongregaci vztahuje k liturgickým teologickým konceptům?

\section{Keywords}

James MacMillan; Congregational music; Catholic liturgical music; $20^{\text {th }}$ - and $21^{\text {st }}$-century music, Participatio actuosa; Liturgical reform; Sacrosanctum concilium

\section{Klíčová slova}

James MacMillan; hudba pro kongregaci; katolická liturgická hudba; hudba 20. a 21. století; participatio actuosa; liturgická reforma; Konstituce o posvátné liturgii

Manfred Novak

University of Music and Performing Arts Graz

Hauptstraße 5/2, 8813 St. Lambrecht, Austria

manfred.novak@gmx.at 